\title{
Implementasi Pemeliharaan Preventif: Pengungkapan Komitmen Manajemen, Kondisi fasilitasi dan Keterampilan
}

\author{
(Preventive Maintenance Implementation: Management \\ Commitment Disclosure, Facilitating Condition and Skill)
}

Oleh:

\author{
Sutarto'; Kaharudin ${ }^{2}$; Nur Mubin ${ }^{3}$; Didi Suryadi ${ }^{4}$ \\ Program Studi Magister Manajemen Universitas Pelita Bangsa1;2;;4) \\ sutartokusuma@gmail1; kaharudin.syach.ks@gmail.coml2; pendidikan.ppai@gmail.com3; \\ Didisuryadi1093@gmail.com ${ }^{4}$
}

Submit: 30 Nov 2020

Review: 07 Dec 2020

Accept: 20 Dec 2020

Publish: 22 Dec 2020

\begin{abstract}
ABSTRAK
Penerapan pemeliharaan preventifmenjadi kebutuhan setiap perusahaan karena dapat memberikan keuntungan produktivitas, namun sampai saat ini belum secara jelas terungkap faktor yang benar-benar mempengaruhinya. Penelitian ini berupaya menganalisis pengaruh pengungkapan komitmen manajemen dan kondisi fasilitasi dari sudut pandang karyawan serta ketrampilan karyawan dalam mempengaruhi penerapan pemeliharaan preventif. Penelitian dilakukan dengan memberikan kuesioner kepada 64 karyawan pelaksana pemeliharaan di kawasan Industri Cikarang. Penelitian menggunakan metode kuantitatif yaitu analisis regresi linier ganda. Penelitian menunjukkan bahwa pengungkapan komitmen manajemen, kondisi fasilitasi dan keterampilan berpengaruh terhadap penerapan pemeliharaan preventif dengan arah positif. Keterampilan karyawan menjadi faktor utama yang mempengaruhi penerapan pemeliharaan preventif, kemudian komitmen manajemen dan terakhir kondisi fasilitasi.
\end{abstract}

Kata kunci:

Pengungkapan Komitmen manajemen; Kondisi fasilitasi; Keterampilan; Implementasi Pemeliharaan Preventif

\section{ABSTRACT}

Preventive maintenance implementation is a necessity for every company because it can provide productivity benefits, but until now it has not been clearly revealed that factors really influence it. The aim of this study is to analyze the effect of management commitment disclosure and facilitating conditions and employee skills toward preventive maintenance implementation. The research data find out from questionnaires which is to 64 maintenance staff in the Cikarang industrial area. This research uses a quantitative method which is multiple linear regression analysis. Research shows that management commitment disclosure, facilitating conditions, and skills affect the preventive maintenance implementation in a positive direction. Employee skills are the main factor influencing the 
implementation of preventive maintenance, then management commitment disclosure, and finally the facilitating condition.

Keywords:

Management Commitment Disclosure; Facilitating Conditions; Skill; Preventive Maintenance Implementation

\section{PENDAHULUAN}

$\begin{array}{ccr}\text { Dunia } & \text { industri } & \text { manufaktur } \\ \text { merupakan } & \text { rangkaian } & \text { kegiatan } \\ \text { operasional } & \text { secara kontinue } & \text { untuk }\end{array}$ menghasilkan barang dalam pemenuhan kebutuhan konsumen secara komplek dengan sekala luas. Kemudian banyak hal yang harus dilakukan agar operasional tetap berjalan dengan tanpa gangguan dari mesin mesin penunjang kegiatan operasional. Perusahaan perlu merancang perawatan yang tepat strategi, adapun jenis kegiatan perawatan terdiri berbagai rangkaian pekerjaan yang saling berkaitan antara satu dengan kegiatan lainnya. Salah satu sistem pemeliharaan dalam suatu industri adalah implementasi pemeliharaan preventif, yang merupakan seperangkat aturan yang menjelaskan mekanisme untuk perawatan. Hal ini perlu dilakukan untuk menjaga semua kegiatan operasional tetap berjalan dengan baik.

Kegiatan industri menghindari permasalahan yang berkaitan dengan kerusakan mesin karena hal tersebut akan menyebabkan terganggunya kegiatan operasional kemudian pada akhirnya target tidak tercapai, biaya tinggi bahkan adanya complain dari konsumen. Tentunya hal itu semua bisa diatasi dengan metode melakukan kegiatan perawatan rutin.

Sumber peneliti terdahulu (Zhou, 2014) menyampaikan pendapat dan hasilnya mengenai pembahasan tentang kegiatan perawatan berikut point pentingnya kegiatan tersebut.
Pemeliharaan terencana adalah kombinasi antara prediksi dan pemeliharaan preventif, yaitu praktek umum di berbagai industri, dimana mesin komponen diganti secara berkala (Jacky Chin, Herlina, ShuChiang Lin, Satria Fadil Persada, Choesnul Jaqin, Ilma Mufidah, 2019). Pemeliharaan (maintenance) adalah suatu kombinasi dari berbagai tindakan yang dilakukan untuk menjaga suatu barang atau memperbaikinya sampai pada suatu kondisi yang bisa diterima. Tujuan Pemeliharaan adalah sebagai berikut: 1) Menjamin keselamatan dan keamanan user dan lingkungan sekitar; 2) Memperpanjang usia kegunaan alat; 3)Kualitas ketepatan alat lebih terjamin; 4) Kuantitas Stop peralatan dapat dikurangi down time peralatan; 5) Menjamin kesiapan operasional peralatan setiap saat; 6) Biaya perbaikan yang mahal dapat dikurangi; 7) Mendapatkan laba investasi yang maksimum (Wirson, Iwan Krisnadi 2019). Kemudian dari sumber lain menyampaikan bahwa Pemeliharaan (maintenance) mencakup keseluruhan aktivitas yang bertujuan untuk menjaga keseluruhan peralatan sistem agar dapat bekerja, memperpanjang umur pakai fasilitas produksi, menjamin kesiapan operasional seluruh fasilitas, menjamin keselamatan operator, mendukung kemampuan mesin untuk dapat memenuhi kebutuhan sesuai fungsinya, serta untuk mencapai tingkat biaya perawatan optimal (Tri Satya Pradnyandari, Ni Ketut Purnawati, 2019). 
Kemudian dalam mempertahankan tingkat persaingan dan kelangsungan perusahaan maka Komitmen Manajemen merupakan faktor yang sangat penting. Salah satunya adalah komitmen manajemen terhadap kegiatan implementasi preventive maintenance. Kegagalan dalam mengimplementasikan preventive maintenance mempunyai dampak menyeluruh dalam organisasi. Oleh karena itu komitmen menajemen merupakan faktor yang mempengarui berjalan dengan baik atau tidak berjalannya kegiatan preventive maintenance sehingga peran manajemen diperlukan menjadi satuan pendukung pelaksanaan kegiatan preventive maintenance.

Seperti disampaikan oleh peneliti sebelumnya bahwa untuk meningkatkan daya saing, perusahaan manufaktur berupaya mengurangi aktivitas yang menambah nilai produk tetapi menghasilkan biaya, dan dalam pengertian ini, salah satu cara untuk mengurangi pemborosan adalah dengan mengadopsi pendekatan manajemen yaitu adanya komitmen (José Roberto Díaz-Reza, Jorge Luis García-Alcaraz, Liliana Avelar-Sosa 2018).

Namun demikin komitmen manajemen bukan satu satunya faktor yang dapat mempengarui tingkat kepuasan pemeliharaan preventif. Hal ini peneliti lain memyampaikan bahwa hanya sedikit penelitian yang tersedia mengenai faktor-faktor yang mempengaruhi keberhasilan sistem pemeliharaan adalah di fasilitas manufaktur (Choesnul Jaqin, Ilma Mufidah 2019). Selain itu kemampuan individu juga menjadi faktor pengaruh terhadap implentasi preventive maintenance. Dengan mempertimbangkan biaya dari sumber daya yang digunakan. Indikator produktivitas kerja meliputi kemampuan, meningkatkan hasil yang dicapai, semangat kerja, pengembangan diri, mutu, serta efisiensi (Elisa Nurisa Sumajow, Bernhard Tewal, Genita G Lumintang, 2018).

Adanya berbagai macam temuan yang berbeda dimana hanya komitmen manajemen yang mempengaruhi implementasi preventive maintenance, sementara pada penelitian lain masih banyak faktor yang dapat mempengaruhi implementasi mendorong dilakukannya penelitian ini untuk mendapatkan gambaran yang lebih jelas. Penelitian ini menjadi lebih menarik dan menantang karena dilakukan di daerah kawasan industri cikarang, sebuah wilayah sebagai sentra industri terbesar di Indonesia bahkan Asia Tenggara. Dengan harapan hasil penelitian ini merupakan bagian kepentingan semua industri dalam meningkatkan daya saing skala Nasional maupun Internasional. Pada penelitian ini akan mengkombinasikan komitmen manajemen (José Roberto Díaz-Reza, Jorge Luis García-Alcaraz, Liliana Avelar-Sosa, 2018), kondisi fasilitasi dan keterampilan (Jacky Chin, Herlina, Shu-Chiang Lin, Satria Fadil Persada, 2019) dalam mempengaruhi implementasi pemeliharaan preventif. Lebih rincinya variabel tersebut yang nantinya menjadi point penting dalam penelitian ini. Kemudian alasan melakukan penelitian ini ditemukan beberapa indikator sebagai Analisa lebih lanjut. Adapun indikator komitmen manajemen adalah: 1) tanggung jawab pimpinan departemen terhadap preventive maintenance, 2) Manajer puncak memimpin pelaksanaan pemeliharaan preventive, 3) Manajer puncak terlibat langsung dalam proyek pemeliharaan, 4) Pertemuan diadakan antara departemen produksi dan pemeliharaan. Faktor lain yang 
berpengaruh adalah fasilitator komitmen terhadap preventive maintenance dengan indicator sebagai berikut; 1) Perusahaan memiliki sumber daya yang diperlukan untuk mendukung aktivitas pemeliharaan, 2) Sistem pemeliharaan kompatibel dengan sistem lainnya di perusahaan, 3) Perusahaan memiliki fasilitas yang diperlukan untuk mendukung aktivitas pemeliharaan, 4) Perusahaan memiliki fasilitas system untuk mendukung proses pemeliharaan. Kemudian variabel skill individu juga mempunyai pengaruh terhadap implementasi preventive maintenance, Adapun indicator pendukung adalah, 1) kompetensi yang diperlukan untuk melakukan kegiatan pemeliharaan preventive, 2) Keterampilan teknisi sesuai dengan sistem pemeliharaan, 3) kemampuan pengembangan dalam melakukan aktifitas pemeliharaan, 4) memiliki pengetahuan untuk melakukan aktivitas pemeliharaan.

Implementasi preventive maintenance menjadi penting karena merupakan upaya awal untuk memastikan kelancaran semua peralatan penunjang proses kegiatan produksi. Sayangnya, hasil penemuan penelitian sebelumnya tentang komitmen manajemen hanya dilihat dari pihak manajemen, sedangkan implementasi sesungguhnya belum terungkap. Kondisi fasilitator dan skill individu yang ada selama ini hanya mempengaruhi peralatan, durasi, tingkat kompetensi ketrampilan, tingkat kerumitan mesin, tingkat fasilitas, tingkat kepuasan pelaksanaan preventive maintenance. Hal tersebut belum secara tegas menunjukkan pengaruhnya terhadap implementasi preventive maintenance.

Dalam penelitian ini berupaya mengungkap implementasi preventive maintenance dari sudut pandang karyawan sebagai pelaksana sehingga komitmen manajemen lebih bisa diarahkan pada pengungkapan dari sudut pandang manajemen seperti yang sudah diungkap pada peneliti sebelumnya, dengan harapan bisa mengungkap ada atau tidaknya peran karyawan. Selain itu kondisi fasilitasi dan skill individu akan ditambahkan sebagai faktor yang dapat mempengaruhi implementasi pemeliharaan preventif.

\section{METODE PENELITIAN \\ Desain Penelitian}

Implementasi pemeliharaan preventif merupakan pemeliharaan secara khusus dibangun untuk penelitian ini dengan menggabungkan empat faktor eksternal dan dua faktor internal. Untuk mengevaluasi penerapan sistem pemeliharaan preventif, empat faktor dieksplorasi dalam evaluasi alat, durasi, tingkat kompetensi keterampilan dan tingkat kompleksitas mesin. Sumber penelitian sebelumnya menyampaikan bahwa bahwa kebijakan manajer puncak dalam hal pengambilan keputusan merupakan salah satu indikator utama yang membentuk konstruk komitmen manajemen (Sigit Priyono, Machfud, Agus Maulana, 2019). Komitmen manajemen itu sendiri akan mempengaruhi implementasi pemeliharaan preventif (José Roberto DíazReza, Jorge Luis García-Alcaraz, Liliana Avelar-Sosa, 2018). Hipotesis pertama yaitu komitmen manajemen berpengaruh positif terhadap implementasi preventive maintenance.

Faktor lain yang mempengaruhi TPM adalah kelancaran operasi perusahaan, tidak terlepas dari kemampuan manajemen dalam pengelolaannya (Sutrisno, 2017). Sumber lain menyatakan bahwa meningkatkan kompetensi sumber daya manusia baik melalui training, workshop dan komitmen terhadap nilainilai perusahaan (M. Imam Muttaqijn, 
Peppy Aji, 2020). Selain itu juga ditegaskan pula bahwa kondisi fasilitasi yang baik dapat meningkatkan pemeliharaan preventif (Jacky Chin, Herlina, Shu-Chiang Lin, Satria Fadil Persada, 2019). Hipotesis kedua yaitu kondisi fasilitasi berpengaruh positif terhadap implementasi pemeliharaan preventif.

Dalam rangka mencapai tujuan suatu organisasi baik organisasi besar maupun kecil, fungsi pengawasasn merupakan unsur yang penting demi kelangsungan dan pertumbuhan serta keselamatan organisasi yang bersangkutan (Hidayat, Agus Suprianto 2019). Dalam meningkatkan total productive maintenance, karyawan harus memiliki pemahaman tujuan operasi (Sutrisno, 2017). Penerapan TPM yang efektif untuk menunjang peningkatan produktivitas pabrik perlu didukung oleh upaya perbaikan pelaksanaan program penggantian komponen dalam planned maintenance dan penerapan pilar autonomous maintenance (Sigit, 2019). Pelaksanaan program tersebut membutuhkan keterampilan karyawan sehingga dapat mendorong meningkatnya TPM (Jacky Chin, Herlina, Shu-Chiang Lin, Satria Fadil Persada, 2019). Hipotesis ketiga yaitu keterampilan individu berpengaruh positif terhadap implementasi pemeliharaan preventif.

Desain penelitian tersebut memunculkan variabel penelitian yaitu tiga variabel independen dan satu variabel dependen. Dari proposi atau dugaan menciptakan tiga hipotesis penelitian yaitu pengaruh komitmen manajemen, kondisi fasilitator dan skill individu terhadap implementasi preventive maintenance. Desain penelitian tersebut

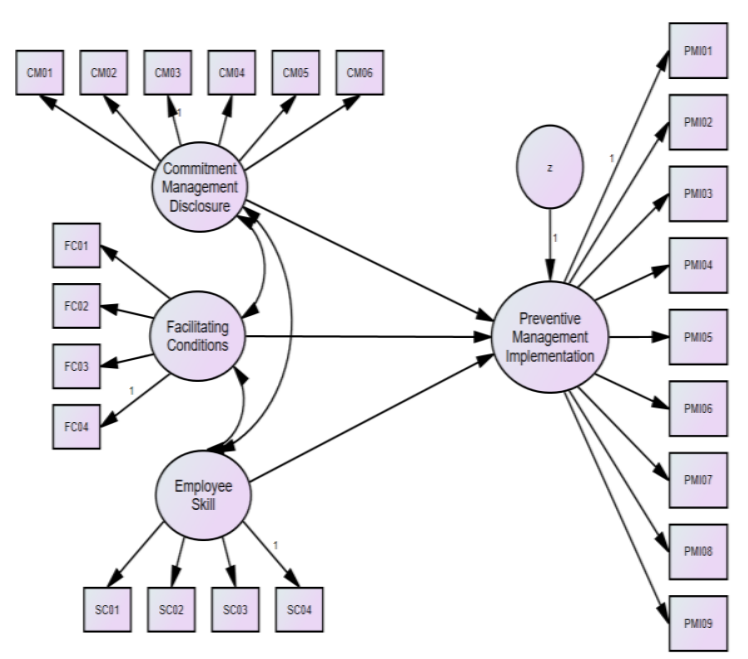

Gambar 1. Desain Penelitian

\section{Sampling}

Dalam melakukan penelitian penulis menggunakan metode Kuantitatif, menurut Sugiono (2016), metode kuantitatif adalah pendekatan ilmiah yang memandang suatu relitas itu dapat diklasifikasikan konkrit, teramati dan terukur. Penyebaran kuesioner kepada responden menggunakan teknik nonprobality sampling. Kuesioner dilakukan dengan menyusun pernyataan tentang variabel-variabel yang diteliti ditujukan 64 karyawan bagian Pemeliharaan di wilayah kawasan Industri Cikarang.

\section{Metode Analisis}

Data dari hasil kuesioner digunakan sebagai data analisis. Prosedur analisis di dahului dengan pengujian instrumen (validitas-reliabilitas) karena masingmasing variabel diukur dengan banyak indikator pengukur. Selanjutnya dilakukan analisis utama yaitu regresi linier ganda (uji persyaratan analisis/asumsi klasik, uji model dan uji hipotesis).

Uji validitas digunakan untuk mengukur sah atau valid tidaknya suatu kuesioner. Pengujian ini dilakukan dengan cara menghitung korelasi antara nilai yang 
diperoleh dari setiap pernyataan. Apabila signifikansi Pearson Correlation yang didapat memiliki nilai dibawah 0,05 berarti data yang diperoleh adalah valid.

Uji reliabilitas dilakukan untuk mengukur suatu kuesioner yang merupakan indikator dalam variabel dan konstruk. Pengujian reliabilitas diukur dengan menggunakan uji statistik Cronbach Alpha (a) dengan metode one shot, yaitu dimana pengukuranya dilakukan hanya sekali dan kemudian hasilnya dengan pertanyaan lain atau mengukur korelasi antar jawaban pertanyaan. Suatu konstruk atau variabel dikatakan reliable jika memberikan nilai a > 0,70 (Nunnally, 1994 dalam Ghozali, 2016).

Uji persyaratan analisis dilakukan melalui uji asumsi klasik yang terdiri dari uji normalitas, multikolinieritas, autokorelasi dan hateroskedastisitas. Uji normalitas dilakukan dengan uji Kolmogorov-Smirnov yaitu menentukan normalitas distribusi residual dimana jika sig atau p-value >0,05, maka data berdistribusi normal atau model regresi yang baik adalah data yang berdistribusi normal atau mendekati norma (Ghozali, 2011: 160-165).

Multikolinearitas terjadi jika antara semua atau beberapa variabel penjelas terdapat hubungan yang kuat dalam memakai model regresi. Pengujian gejala multikoloniearitas bisa dilihat dari nilai Tolerance Value atau Variance Inflection Factors (VIF). Dengan demikian, tolerance yang rendah nilainya sama dengan nilai VIF yang tinggi dan hal ini menunjukkan koloniearitas juga tinggi. Adanya multikolinearitas terindikasi jika nilai VIF $>10$.

Terjadi atau tidak terjadinya autokorelasi diuji dengan menggunakan pendekatan uji Durbin Watson (DW).
Pengujian dilakukan dengan mencari nilai batas bawah (dL) yang dihasilkan dan batas atas (dU) sehingga tidak terjadinya autokorelasi jika du $<\mathrm{dw}<4$-du.

Uji heteroskedastisitas dilakukan agar diketahui apakah dalam model regresi terjadi ketidaksamaan varian dari residual antara satu pengamatan ke pengamatan lainnya dan kesalahan tidak bersifat acak atau random. Pengujian dilakukan dengan metode grafik yaitu dengan mengamati scatterplot dimana nilai Predicted Standardized digambarkan pada sumbu horizontal sedangkan nilai Residual Studentized digambarkan pada sumbu vertikal. Jika scatterplot menyebar dengan acak maka menunjukan tidak terjadi masalah heteroskedastisitas pada model regresi yang terbentuk.

Uji model dilakukan menggunakan analisis koefisien determinasi dan uji-F. Nilai koefisien determinasi untuk mengukur tingkat kemampuan model dalam memberikan penjelasan atas variabel independen (Imam Ghozali, 2011: 97). Uji-F digunakan untuk memastikan bahwa nilai koefisien determinasi signifikan sehingga dapat digunakan sebagai prediktor model. Jika nilai sig (signifikansi) < 0,05 maka model persamaan regresi hasil analisis dinyatakan layak dan analisis dapat berlanjut ke pengujian hipotesis.

Pengujian hipotesis dilakukan dengan menggunakan persamaan regresi linier ganda dan uji-t. Model persamaan regresi linier ganda yang dimaksud adalah: $\mathrm{PMI}=\mathrm{a}+\mathrm{b} 1 \mathrm{CM}+\mathrm{b} 2 \mathrm{FC}+\mathrm{b} 3 \mathrm{SC}$

Pengujian dilakukan terhadap nilai koefisien regresi masing-masing variabel yang menunjukkan besar dan arah pengaruh secara parsial. Apabila probabilitas sig $<0,05$ maka nilai koefisien regresi signifikan dan dapat diterjemahkan karena hipotesis diterima. 


\section{HASIL PENELITIAN}

\section{Responden}

Responden pada penelitian ini adalah pegawai 64 karyawan pemeliharaan yang berada di Kawasan Industri Cikarang. Rentang usia karyawan adalah antara 19 tahun sampai dengan 53 tahun. Sebagian besar responden adalah laki-laki (93.8\%) dan sisanya adalah perempuan.
Pendidikan tersebar dari SLTA, Diploma dan Sarjana dimana jumlah terbanyak adalah pegawai dengan pendidikan SLTA $(64,1 \%)$.

\section{Uji Instrumen}

Hasil uji instrumen variabel penelitian selengkapnya dapat dilihat pada tabel 1 yaitu uji validitas reliabilitas..

Tabel 1. Validitas dan Reliabilitas

\begin{tabular}{|c|c|c|}
\hline Variabel/Indikator & $\mathrm{CA} / \mathrm{r}$ & Hasil Uji \\
\hline Pengungkapan Komitmen Manajemen & 0.830 & Reliabel \\
\hline - Pimpinan departemen menunjukkan tanggung jawab pemeliharaan preventive & 0.731 & Valid \\
\hline - Manajer menunjukkan keseriusan dalam pemeliharaan preventive & 0.430 & Valid \\
\hline - Manajer puncak aktif memfasilitasi pemeliharaan & 0.618 & Valid \\
\hline - Manajer menunjukkan perhatian pada staf pemeliharaan & 0.513 & Valid \\
\hline - Manajer puncak mendorong keberlanjutan tim kerja pemeliharaan & 0.739 & Valid \\
\hline - Manajer puncak menunjukkan keseriusan dalam pemeliharaan. & 0.679 & Valid \\
\hline Kondisi Fasilitasi & 0.902 & Reliabel \\
\hline - Perusahaan menyediakan sumber daya pendukung pemeliharaan preventive & 0.766 & Valid \\
\hline - Karyawan mendapat sistem pemeliharaan preventive yang kompatibel & 0.666 & Valid \\
\hline - Karyawan mendapat fasilitas pendukung aktivitas pemeliharaan preventive & 0.807 & Valid \\
\hline - Karyawan mendapat akses fasilitas system proses pemeliharaan & 0.900 & Valid \\
\hline Keterampilan & 0.868 & Reliabel \\
\hline - Karyawan memiliki kompetensi pemeliharaan preventive & 0.735 & Valid \\
\hline - Keterampilan teknisi sesuai dengan sistem pemeliharaan preventive & 0.783 & Valid \\
\hline - Karyawan memiliki pengetahuan pemeliharaan preventive & 0.826 & Valid \\
\hline $\begin{array}{l}\text { - Karyawan memiliki kemampuan pengembangan dalam melakukan aktifitas } \\
\text { pemeliharaan preventive }\end{array}$ & 0.623 & Valid \\
\hline Implementasi Pemeliharaan Prefentif & 0.966 & Reliabel \\
\hline - Pelaksanaan pemeliharaan sesuai dengan prosedur & 0.847 & Valid \\
\hline - Karyawan melakukan tindak lanjut kegiatan pemeliharaan & 0.859 & Valid \\
\hline - Manajer aktif terlibat dalam kegiatan pemeliharaan & 0.886 & Valid \\
\hline - Manajer aktif memimpin pelaksanaan pemeliharaan preventive & 0.902 & Valid \\
\hline - Departemen produksi terlibat dalam pemeliharaan preventive & 0.846 & Valid \\
\hline - Pimpinan teknik aktif mengarahkan pemeliharaan preventive & 0.880 & Valid \\
\hline - Terdapat komunikasi antara departemen produksi dan pemeliharaan. & 0.897 & Valid \\
\hline - Terdapat pengetahuan tentang sistem mesin kritis. & 0.803 & Valid \\
\hline $\begin{array}{l}\text { - Kegiatan pemeliharaan preventive difokuskan pada siklus hidup sistem, suku } \\
\text { cadang dan komponen alat berat. }\end{array}$ & 0.771 & Valid \\
\hline
\end{tabular}

Sumber: Data penelitian diolah, 2020 
Tabel 2. Deskripsi Variabel

\begin{tabular}{lccccc}
\hline \multicolumn{1}{c}{ Variabel } & $\mathrm{N}$ & Minimum & Maximum & Mean & Kategori \\
\cline { 1 - 2 } & 64 & 5.00 & 10.00 & 8.3281 & Sangat Tinggi \\
FC & 64 & 4.00 & 10.00 & 8.3633 & Sangat Baik \\
SC & 64 & 5.00 & 10.00 & 8.5312 & Sangat Tinggi \\
PMI & 64 & 3.00 & 10.00 & 8.4045 & Sangat Baik \\
Valid N (listwise) & 64 & & & & \\
\hline
\end{tabular}

Sumber: Data penelitian diolah, 2020

\section{Uji Asumsi Klasik}

Uji normalitas grafik menghasilkan data residual di sekitar garis diagonal dan mengikuti arah garis diagonalnya, maka model regresi memenuhi asumsi normalitas. Uji normalitas KolmogorofSmirnov Test terhadap nilai residual model regresi memiliki signifikansi 0,200 > 0.05 yang menunjukkan bahwa model regresi yang digunakan mempunyai standar error yang normal atau berasal dari data yang berdistribusi normal sehingga normalitas terpenuhi.

Multikolinearitas menunjukkan bahwa antara variable independent mempunyai hubungan langsung (korelasi) yang sangat kuat. Multikolinearitas terjadi jika nilai Variance Inflation Factor (VIF) lebih besar dari 10 atau nilai Tolerance lebih kecil 0,10. Hasil analisis menunjukkan bahwa variabel independen pada model yang digunakan mempunyai nilai VIF kurang dari 10 (Budaya organisasi 1,288; Kompetensi 1,762; Kepuasan 1,66) yang berarti variabel independen yang digunakan pada model persamaan regresi tidak ada multikolinearitas (tidak ada hubungan yang sangat kuat antara variabel independen).

Autokorelasi menunjukkan bahwa ada korelasi antara error dengan error periode sebelumnya dimana pada asumsi klasik hal ini tidak boleh terjadi. Uji autokorelasi dilakukan dengan menggunakan Durbin Watson. Jika nilai Durbin Watson berkisar diantara nilai batas atas (dU) maka diperkirakan tidak terjadi pelanggaran autokorelasi. Nilai batas bawah (dL) yang dihasilkan pada model persamaan adalah sebesar 1,5991, dengan batas atas (dU) sebesar 1,7306. Hasil uji durbin watson statistik didapat sebesar 2,208 berada diarea $\mathrm{du}<\mathrm{dw}<4-\mathrm{du}$, atau berada di area tidak ada autokorelasi. Maka dapat disimpulkan bahwa tidak ada autokorelasi pada model regresi yang digunakan.

Heteroskedastisitas menunjukkan bahwa varians dari setiap error bersifat heterogen yang berarti melanggar asumsi klasik yang mensyaratkan bahwa varians dari error harus bersifat homogen. Jika varian dari residual satu pengamatan ke pengamatan yang lain tetap, maka disebut homoskedastisitas dan jika berbeda disebut heteroskedastisitas. Model regresi yang baik adalah model yang tidak terjadi heteroskedastisitas (Ghozali, 2009).

Uji Heterokedastisitas melalui metode Glejser Test diketahui bahwa seluruh variabel independen yaitu komitmen manajemen, kondisi fasilitasi dan individual skill memiliki nilai sig. $>0,05$ (CM 0,810; FC 0,902; SC 0,868) yang berarti varians error dinyatakan homogen 
sehingga tidak terdapat permasalahan heteroskedastisitas. Dengan demikian asumsi atas heteroskedastisitas pada model persamaan regresi telah terpenuhi.

\section{Uji Model}

Pengujian model memerlukan nilai koefisien determinasi dan uji-F. Nilai koefisien determinasi diperolah dari hasil analisis pada tabel 3 .

Tabel 3. Koefisien Determinasi

\begin{tabular}{ccccc}
\hline \multicolumn{5}{c}{ Model Summary } \\
\hline Model & $\mathrm{R}$ & R Square & Adjusted R Square & $\begin{array}{c}\text { Std. Error of the } \\
\text { Estimate }\end{array}$ \\
\hline 1 & $.924^{\mathrm{a}}$ & .854 & .846 & .49054 \\
\hline
\end{tabular}

a. Predictors: (Constant), Skill Compet, Commitment Manag., Facilitating Conditions b. Dependent Variable: Preventive Maintenance Implementation Sumber: data diolah, 2020

Tabel 4. Uji Model / Uji-F

\begin{tabular}{cccc}
\hline Variabel & \multicolumn{3}{c}{ Dependen: Disiplin } \\
\cline { 2 - 4 } Independen & $F_{\text {hitung }}$ & Sig. & Kesimpulan \\
\hline CM, FC, SC & 116,693 & 0,000 & $\mathrm{H}_{0}$ ditolak \\
\hline
\end{tabular}

Sumber: data diolah, 2020

Nilai adjusted R Square adalah sebesar 0,846 pada model yang digunakan, artinya implementasi pemeliharaan preventif hanya mampu dijelaskan oleh variasi dari variabel independennya yaitu sebesar $84,6 \%$. Kelayakan model harus dibuktikan melalui uji $\mathrm{F}$ dimana pengujian dilakukan berdasarkan hasil analisis pada tabel 3 .

Hasil Uji $F$ menggunakan analisis varians (ANOVA) bahwa nilai Fhitung yang diperoleh pada model yang digunakan sebesar 116,693 dengan nilai sig. yang dihasilkan sebesar 0,000 yang mampu menyatakan bahwa seluruh variabel independen yaitu Pengungkapan komitmen manajemen, kondisi fasilitasi dan keterampilan pegawai layak digunakan untuk memprediksi implementasi pemeliharaan preventif.

\section{Uji Hipotesis}

Untuk keperluan pengujian hipotesis diperlukan model persamaan regresi linier ganda dan nilai probabilitas untuk melakukan uji-t dimana data tersebut merupakan hasil analisis yang disajikan pada tabel 5 .

Model persamaan regresi linier ganda hasil analisis sebagaimana tercantum pada tabel 6 adalah sebagai berikut:

$\mathrm{Y}=-1,130+0,403 \mathrm{CM}+0,296 \mathrm{FC}+0,434 \mathrm{SC} . . .(2)$

Variabel CM menghasilkan nilai koefisien yang positif terhadap PMI yaitu sebesar 0,403 dengan nilai probabilita sebesar 0,001. Nilai probabilitas (Sig.) yang dihasilkan lebih kecil dari tingkat signifikansi 5\% (0,135 > a0,05) sehingga dapat menyatakan bahwa CM memiliki pengaruh yang signifikan terhadap PMI, maka hipotesa 1 diterima. 
Nilai koefisien FC positif sebesar 0,296 dengan nilai probabilitas sebesar 0,003. Nilai probabilitaa (Sig.) yang dihasilkan lebih kecil dari tingkat signifikansi 5\% $(0,000<a 0,05)$ sehingga disimpulkan FC memiliki pengaruh yang signifikan terhadap PMI, maka hipotesis 2 diterima.
Nilai koefisien SC positif sebesar 0,434 dengan nilai probabilita sebesar 0,000. Nilai probabilitas (Sig.) yang dihasilkan lebih kecil dari tingkat signifikansi 5\% $(0,000<a 0,05)$ sehingga disimpulkan SC memiliki pengaruh yang signifikan terhadap PMI, maka hipotesa 3 diterima.

Tabel 5. Pengujian Hipotesis

\begin{tabular}{cccc}
\hline \multirow{2}{*}{$\begin{array}{c}\text { Variabel } \\
\text { Independen }\end{array}$} & \multicolumn{2}{c}{ Dependen: PMI } & \\
\cline { 2 - 3 } Koefisien & Sig. & Kesimpulan Hipotesis \\
\hline (Constant) & $-1,130$ & 0,038 & - \\
CM & 0,403 & 0,001 & H1 diterima \\
FC & 0,296 & 0,003 & H2 diterima \\
SC & 0,434 & 0,000 & H3 diterima \\
\hline
\end{tabular}

Sumber: Data diolah, 2020

\section{PEMBAHASAN}

\section{Pengaruh Pengungkapan Komitmen manajemen Terhadap Implementasi Pemeliharaan Preventif}

Penelitian menghasilkan nilai koefisien positif dan signifikan antara komitmen menajemen terhadap implementasi preventive maintenance. Hasil tersebut menyimpulkan bahwa komitmen manajemen yang telah tertanam dan dilaksanakan atau bahkan menjadi sebuah aturan dalam sebuah instansi dapat membuat peningkatan implementasi pemeliharaan preventif dalam dunia industri. Komitmen manajemen yang terungkap dan dapat dirasakan karyawan akan mendorong perbaikan dalam implementasi pemeliharaan preventif (José Roberto Díaz-Reza, Jorge Luis GarcíaAlcaraz, Liliana Avelar-Sosa, 2018).

Keberhasilan implementasi pemeliharaan preventif ditentukan oleh adanya komitmen manajemen untuk terlibat secara langsung dalam setiap proses. Selain itu juga diperlukan tanggung jawab, keseriusan, keaktifan, perhatian dan dorongan dari manajemen.

\section{Pengaruh Kondisi Fasilitasi Terhadap Implementasi Pemeliharaan Preventif}

Penelitian menghasilkan nilai koefisien positif dan signifikan antara kondisi fasilitasi terhadap implementasi preventive maintenance. Hasil tersebut menunjukkan bahwa kondisi fasilitasi membuat peningkatan implemntasi pemeliharaan preventif. Tersedianya sumber daya pendukung, sistem yang kompatibel, dan akses ke fasilitas sistem proses membuat kegiatan pemeliharaan dapat berjalan dengan baik. Adanya fasilitasi dengan kondisi yang makin baik akan membuat pelaksanaan pemeliharaan preventif menjadi semakin baik pula (Jacky Chin, Herlina, Shu-Chiang Lin, Satria Fadil Persada, 2019). 
Peran pengawas menjadi penting sehingga hasil pelaksanaan preventive sesuai dengan target sasaran yang dicapai. Hal itu akan menjadi semakin baik jika perusahaan menyediakan sumber daya pendukung yang lengkap, sistem yang ompatibel, fasilitas yang cukup dengan akses penuh pada proses pemeliharaan preventive.

\section{Pengaruh Keterampilan Terhadap Implementasi Pemeliharaan Preventif}

Penelitian menghasilkan nilai koefisien positif dan signifikan antara skill individu terhadap implementasi preventive maintenance. Hasil tersebut menyimpulkan bahwa sebagai modal dasar untuk peningkatan implementasi pemeliharaan preventif adalah karyawan yang terampil di bidang pemeliharaan. Karyawan yang kompeten, dengan keterampilan teknis yang sesuai dan pengetahuan luas serta terus mengembangkan diri akan membuat implementasi pemeliharaan preventif akan semakin baik (Jacky Chin, Herlina, ShuChiang Lin, Satria Fadil Persada, 2019).

Keberadaan staf pemeliharaan menjadi begitu penting diantara yang lainnya karena pengaruhnya yang sangat kuat. Oleh karena itu kompetensi, keterampilan teknis, pengetahuan, dan pola pikir karyawan hendaknya terus ditingkatkan dari waktu ke waktu.

\section{KESIMPULAN}

Penelitian ini menghasilkan kesimpulan bahwa pengungkapan komitmen manajemen, kondisi fasilitasi dan keterampilan merupakan prediktor yang dapat mempengaruhi implementasi preventive maintenance, dimana masingmasing memiliki arah positif. Keterampilan merupakan faktor yang paling utama, kemudian kondisi fasilitator dan komitmen manajemen menjadi urutan terakhir.

Perusahaan perlu menjaga dan meningkatkan keterampilan individu dengan harapan implementasi preventive maintenance terlaksana dengan baik dan hal lainya yang tidak kalah penting adalah selalu komitmen manajemen dalam memberikan fasilitas dan sarana untuk implemntasi pemeliharaan preventif.

\section{DAFTAR PUSTAKA}

Adriansyah, M.A., Sintara, I.D., Pramujie, GVC., Salsabila, A., 2020, MENINGKATKAN KOMITMEN ORGANISASI MELALUI PELATIHAN MANAJEMEN DIRI, JURNAL PLAKAT, Jurnal Pelayanan Kepada Masyarakat, Volume 2 No. 1 Juni 2020, 81-89, ISSN: 2714-5239, (Online); ISSN : 2686-0686 (Print).

Chin J., Herlina, Lin, S.C., Persada, S.F. Jaqin, C., Mufidah, I., 2019, Preventive maintenance model for heating ventilation air conditioning in pharmacy manufacturing sector, Int J Syst Assur Eng Manag, https:/ / doi.org/10.1007/ s13198-019-00923-5

Díaz-Reza, J.R., García-Alcaraz, J.L., Avelar-Sosa, L., Mendoza-Fong, J.R., Diez-Muro, J.C.S., and Blanco-Fernández, J., 2018, The Role of Managerial Commitment and TPM Implementation Strategies in Productivity Benefits, Applied Science - Appl. Sci. 2018, 8, 1153; doi:10.3390/app8071153

Heru Mulyanto dan Anna Wulandari, 2010, Penelitian: Metode E Analisis. Semarang: CV.Agung 
Muttaqijn, M.I., Aji, P., 2020, ANALISIS KOMITMEN ORGANISASI DALAM PENINGKATAN TARGET ON TIME PERFORMANCE (OTP) MASKAPAI PENERBANGAN PT. CITILINK INDONESIA, Jurnal Manajemen Bisnis, Vol. 9 I No.2, hal 109-117, ISSN: 2302-3449 I e-ISSN: 2580-9490.

Pitria dan Heru Mulyanto, 2016, Kualitas Layanan dalam Mempengaruhi Komitmen dan Loyalitas Pelanggan Restoran Cepat Saji, Jurnal Manajemen E Kewirausahaan Vol. 13 No. 1 - Juni 2016, 91-99, ISSN: 1858-1048, LP2M STIE IPWIJA

Sigit Priyono, Machfud, Agus Maulana., 2019, Penerapan Total Productive Maintenance (Tpm) pada Pabrik Gula Rafinasi di Indonesia (Studi Kasus: Pt. XYZ): Jurnal Aplikasi Manajemen dan Bisnis, Vol. 5 No. 2, Mei 2019, Permalink/DOI: http://dx.doi.org/10.17358/jabm.5.2.265

Sutrisno, 2017, Kajian Pengaruh Struktur Organisasi, Komitmen Karyawan, dan Pemahaman Tujuan Operasi terhadap Penerapan Total Production Maintanance (TPM) serta Implikasinya pada Kinerja Karyawan, Kontigensi Volume 5, No. 1, Juni 2017, Hal. 57 67, ISSN 2088-4877

Wirson, Iwan Krisnadi, I., 2019, Management Strategi Electronic Preventive Maintenance dengan Metode SWOT untuk Monitoring Standar Pelayanan Peralatan Medik di RSAB. Harapan Kita, InComTech: Jurnal Telekomunikasi dan Komputer, Vol.9, No.1, April 2019, DOI: 10.22441/incomtech.v9i1.5677 